\title{
Origin of andradite in the Quaternary volcanic Andahua Group, Central Volcanic Zone, Peruvian Andes
}

\author{
Andrzej Gałaś ${ }^{1}$ (D) J Jarosław Majka ${ }^{2,3} \cdot$ Adam Włodek $^{2}$ \\ Received: 21 March 2020 / Accepted: 17 February 2021 / Published online: 13 March 2021 \\ (C) The Author(s) 2021
}

\begin{abstract}
Euhedral andradite crystals were found in trachyandesitic (latitic) lavas of the volcanic Andahua Group (AG) in the Central Andes. The AG comprises around 150 volcanic centers, most of wich are monogenetic. The studied andradite is complexly zoned (enriched in $\mathrm{Ca}$ and $\mathrm{Al}$ in its core and mantle, and in $\mathrm{Fe}$ in this compositionally homogenous rim). The core-mantle regions contain inclusions of anhydrite, halite, S- and Cl-bearing silicate glass, quartz, anorthite, wollastonite magnetite and clinopyroxene. The chemical compositions of the garnet and its inclusions suggest their contact metamorphic to pyrometamorphic origin. The observed zoning pattern and changes in the type and abundance of inclusions are indicative of an abrupt change in temperature and subsequent devolatilization of sulfates and halides during the garnet growth. This process is interpreted to have taken place entirely within a captured xenolith of evaporite-bearing wall rock in the host trachyandesitic magma. The devolitilization of sediments, especially sulfur-bearing phases, may have resulted in occasional but voluminous emissions of gases and may be regarded as a potential hazard associated with the AG volcanism.
\end{abstract}

Keywords Andradite $\cdot$ Contact metamorphism $\cdot$ Contamination $\cdot$ Volcanoes $\cdot$ Andahua Group $\cdot$ Andes

\section{Introduction}

Garnet-group silicates are widespread in crustal metamorphic rocks, but are relatively rare in igneous rocks. The chemical and physical characteristics of garnet allow it to record a variety of tectonic, metamorphic, and mantle processes, making these minerals very useful for unraveling the petrogenesis of various rock types. The composition of garnet and coexisting mineral phases can be used to decipher the metamorphic

Editorial handling: A. R. Chakhmouradian

Andrzej Gałaś

agalas@min-pan.krakow.pl

1 Mineral and Energy Economy Research Institute, Polish Academy of Sciences, ul. Wybickiego 7A, 31-261 Krakow, Poland

2 Faculty of Geology, Geophysics and Environmental Protection, AGH University of Science and Technology, al. Mickiewicza 30, 30-059 Krakow, Poland

3 Department of Earth Sciences, Uppsala University, Villavägen 16, 75236 Uppsala, Sweden conditions and the tectonic environments in which they were formed (e.g., Spear 1993; Baxter et al. 2013).

Until now, garnet has not been observed in the relatively poorly studied lavas of the Andahua Group (Venturelli et al. 1978; Delacour et al. 2007; Gałaś 2011) or other lavas from recently active volcanoes in South America. Aggregates of euhedral andradite crystals have now been identified in the trachyandesite from a lava dome located near the Puca Mauras volcano in the Andahua Group (AG), in the Valley of the Volcanoes (Fig. 1a). In this contribution, we describe the mineralogical characteristics of the garnet and its inclusions, and provide some genetic explanation on its origin in predominantly garnet-free volcanic rocks of the AG. We hypothesise on the thus far unrecognised evaporite contamination of these calc-alkaline magmas in the Central Volcanic Zone (CVZ) of the Andes and discuss a range of associated contact metamorphic phenomena (Lacroix 1893). The studied andradite aggregates carried by the AG rocks are interpreted as relicts of pervasively metamorphosed evaporite-bearing xenoliths from the surrounding wall rock. Our data provide evidence for substantial sulfur emission owing to interaction between the lava, its wall rock and xenoliths. 
Fig. 1 a Simplified geological map of the northern part of the Central Volcanic Zone (CVZ) (based on Salcedo 2007; Paulo 2008); $\mathbf{b}$ outline of the location of the CVZ and research area marked by the red rectangle in South America c map (Landsat 7) of the northern part of the Valley of the Volcanoes with locations of the Andahua Group volcanic centres marked. The samples locations for rocks in Table 1 are highlighted red. Sample VV024 contains andradite aggregates

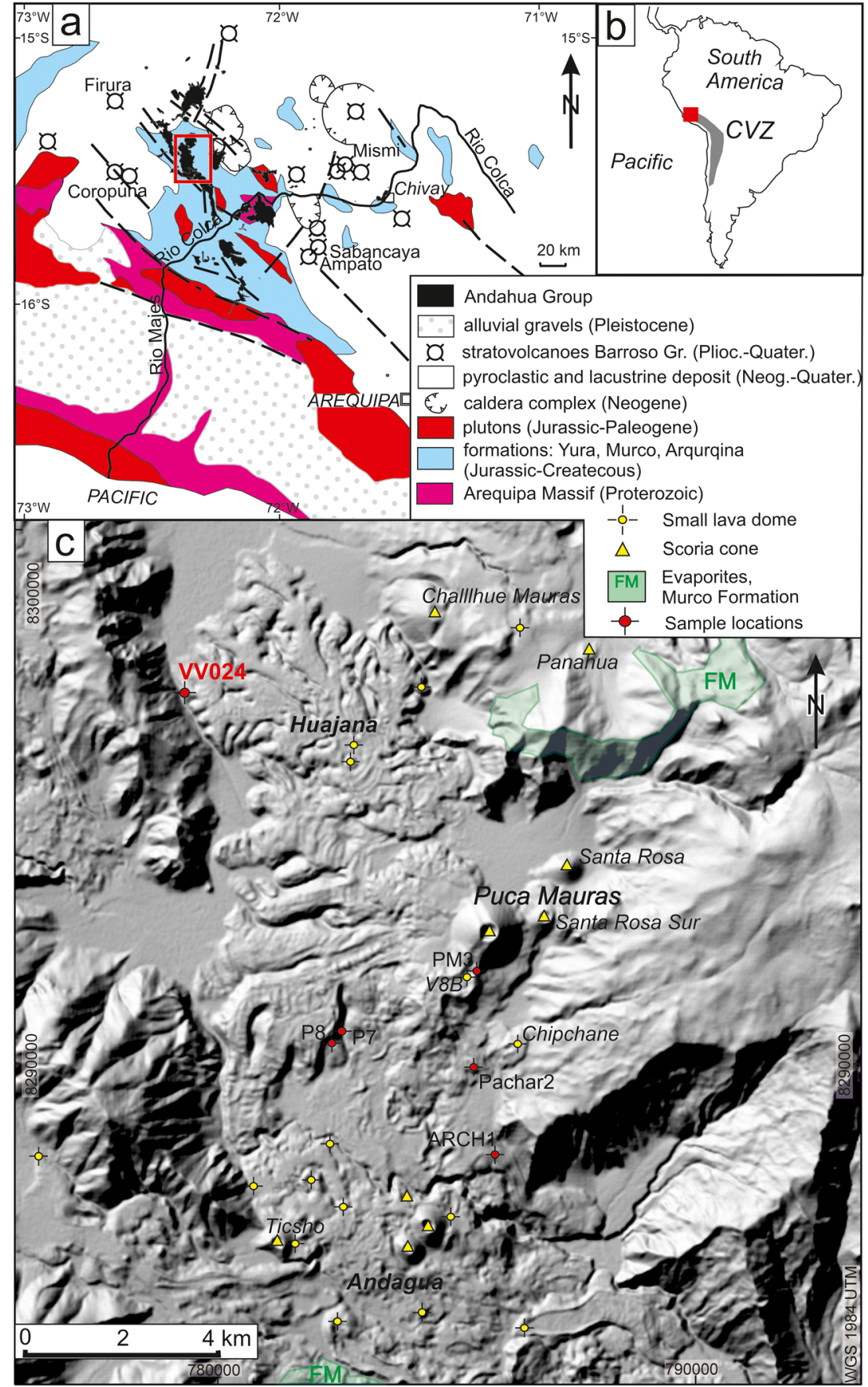

\section{Geological setting}

The study area is located in the Valley of the Volcanoes of the Western Cordillera, in the northern part of the CVZ in the Andes. This part of South America (Fig. 1b) is remarkable due to its continental crust, locally up to $70 \mathrm{~km}$ thick (Beck et al. 1996; Yuan et al. 2002). The Valley of the Volcanoes is located in a transition zone between the Paracas (Paleozoic) and Arequipa (Precambrian) massifs predominantly consisting of granitoids, gneisses and amphibolites (Mamani et al. 2010). These massifs occur to the north and to the south of the study area, respectively. The Valley of the Volcanoes is filled with Mesozoic and Cenozoic sedimentary rocks. These include the Jurassic-Early Cretaceous Yura (sandstones, slates and limestones), and Cretaceous Murco (pyrite-bearing shales, quartzites, gypsum and marls, Fig. 1c), and Arcurqina (marl limestones, claystones with cherts and fossils) Mesozoic formations (Swanson et al. 2004; Mariño and 
Zavala 2016), and widespread Neogene volcano-sedimentary packages, mostly of andesitic to dacitic composition (Mégard 1987; Sébrier and Soler 1991). Pliocene and Holocene tuffs and volcanic conglomerates are locally present on the slopes and at the bottom of the Valley of the Volcanoes (Thouret et al. 2016; De Silva and Kay 2018). The Cenozoic tuff complexes are intruded by subvolcanic dacitic domes (Noble et al. 2003)

Stratovolcanoes are the dominant volcanic form within the northern part of CVZ (De Silva and Francis 1991). The Valley of the Volcanoes is adjacent to the largest, in this part of CVZ, volcanic structure of Nevado Coropuna (6425 $\mathrm{m}$ a.s.l.) to the west (Fig. 1a). To the southeast of the study area, the recently active Sabancaya stratovolcano (5976 m a.s.l.) is located. This is the youngest volcano in Peru, dated to about $6 \mathrm{ka}$ (Samaniego et al. 2016; Bromley et al. 2019). All these structures are collectively known as the Barroso Group. These andesitic and dacitic volcanoes produced lavas with 55-68 wt $\% \mathrm{SiO}_{2}$ in their composition (Wörner et al. 2018), and are interpreted as products of intra-crustal magmatic systems (Mamani et al. 2010). A typical magmatic regime for the CVZ involves multiple magma reservoirs where andesites evolve during frequent mafic recharge events by mixing, fractional crystallization and/or assimilation (Klerkx et al. 1979; Kay et al. 2005; Trumbull et al. 1999). The evolution of each magma batch hosted in a particular reservoir directly depends on the size and temperature of that reservoir, the rate of mafic recharge, and the composition of rocks in the surrounding lower and upper crust (De Paolo 1981). Any changes in these factors can cause eruptions, leading to the creation of various volcanic forms whitin the same area: e.g., calderas, stratovolcanoes and lava domes (Reyes-Guzmán et al. 2018). However, monogenetic scoria cones, representing magmas that did not interact with the crustal rocks during their ascent (Wörner et al. 2018), are also recognized in the study area. The AG is traditionally described as comprising such monogenetic volcanic centers (Delacour et al. 2007; Wörner et al. 2018).

The AG comprises multiple minor volcanic centers (Delacour et al. 2007; Sørensen and Holm 2008). Around 150 vents are observed over an area of 12,000 $\mathrm{km}^{2}$, of which 12 lava fields, 41 lava domes and 23 scoria cones occur in the Valley of the Volcanoes. The AG has been active since the middle of the Pleistocene (Kaneoka and Guevara 1984). The youngest eruptions are ca 300 years old (Cabrera and Thouret 2000). Most typical for the AG are small lava domes, up to 50-70 $\mathrm{m}$ in height (similarly to the Coso Volcanic Field in the USA; Duffield et al. 1980), that are aligned along feeding fissures. The vast majority of the vents erupted by explosive gas release and magma fragmentation in Hawaiian style (Kereszturi and Németh 2011). On the other hand, scoria cones typically result from Strombolianstyle eruptions (Gałaś 2011; Lewińska and Gałaś 2021). It can be concluded that these volcanoes are indeed monogenetic (Delacour et al. 2007; Wörner et al. 2018; sensu Smith and Németh 2017).
The Puca Mauras complex is the largest of the lava fields in the AG and thought to have formed at the end of the Pleistocene (Gałaś 2014; Huang et al. 2017). It consists of five lava domes and three scoria cones. One of the cones, the Puca Mauras volcano (Fig. 1c), reaches $350 \mathrm{~m}$ in height. Its large volume and complex edifice architecture do not fully satisfy the definition of a monogenetic volcano (Gałaś 2011). Lava was emitted by several centers (Gałaś 2011). Lava flows cover the entire width of the valley $(4-6 \mathrm{~km})$ and their total area was calculated to be $\sim 70 \mathrm{~km}^{2}$ and a total volume $\sim 5 \mathrm{~km}^{3}$. The most northerly from the Puca Mauras cone, the Huajana lava field (Fig. 1c) was fed from an isolated lava dome and produced a lava flow having a relative thickness of 40 to $200 \mathrm{~m}$ (Fig. 2a), covering an area of $\sim 22 \mathrm{~km}^{2}$ with a total volume of $\sim 1.5 \mathrm{~km}^{3}$. The flows are built of massive lava, which is slightly porous and partialy blocky closer to the surface.

Based on the chemical TAS classification (Le Maitre et al. 1989), latite is the dominat lithology in the AG. Basaltic trachyandesites and trachytes also occur in minor quantities. The trachyandesites are composed of phenocrysts of plagioclase, clinopyroxene and/or amphibole (Delacour et al. 2007; Gałaś 2014). Xenoliths have been observed in several samples from lava flows in the AG. They differ in size and composition, but most common are granodiorites from the Arequipa Massif, quartzites as well as xenocrystic quartz from the Yura Formation. The largest ones are about $15 \mathrm{~cm}$ in diameter, whereas the smallest clasts are microscopic. Due to their light colours and mineral composition, they can be easily distinguished from the parental lava. There is no specific pattern in the occurrence of these xenoliths. Xenoliths composed of garnet are scarce. Sample VV024 studied in this work represents such a xenolith.

\section{Sampling and methods}

About 150 samples of volcanic rocks were collected during several expeditions to the study area. The largest set of samples in this collection consists of lavas and pyroclastic rocks that represent all of the lava fields in the AG (Gałaś 2011). The settlement in this part of the Valley of the Volcanoes is now called Andagua (Fig. 1c); however, in geological studies (Caldas et al. 2001; Delacour et al. 2007; Gałaś 2014; Mariño and Zavala 2016), the name of the rock formation uses the former spelling of the town's name, thus Andahua Group. The garnet aggregate described in this study was found at the front of the Huajana lava flows, $8 \mathrm{~km}$ northwest of the Puca Mauras volcano (sample VV0024: near $15^{\circ} 22.8^{\prime} \mathrm{S}$, $72^{\circ} 23.9^{\prime} \mathrm{W}$ ) during the 2017 field campaign within the recently established Geopark Colca and Volcanoes of Andagua (Gałaś et al. 2018). Detailed geochemical data of the AG rocks can be found in Gałaś (2014). However, for the purpose of present work, bulk chemical analyses of additional five 
Fig. 2 a Lava flow cut by the Andagua River near AndaguaOrcopampa road. The garnetbearing sample (VV024) was collected in the lower part of the channel wall; b Trachyandesite dyke in the Colca Canyon
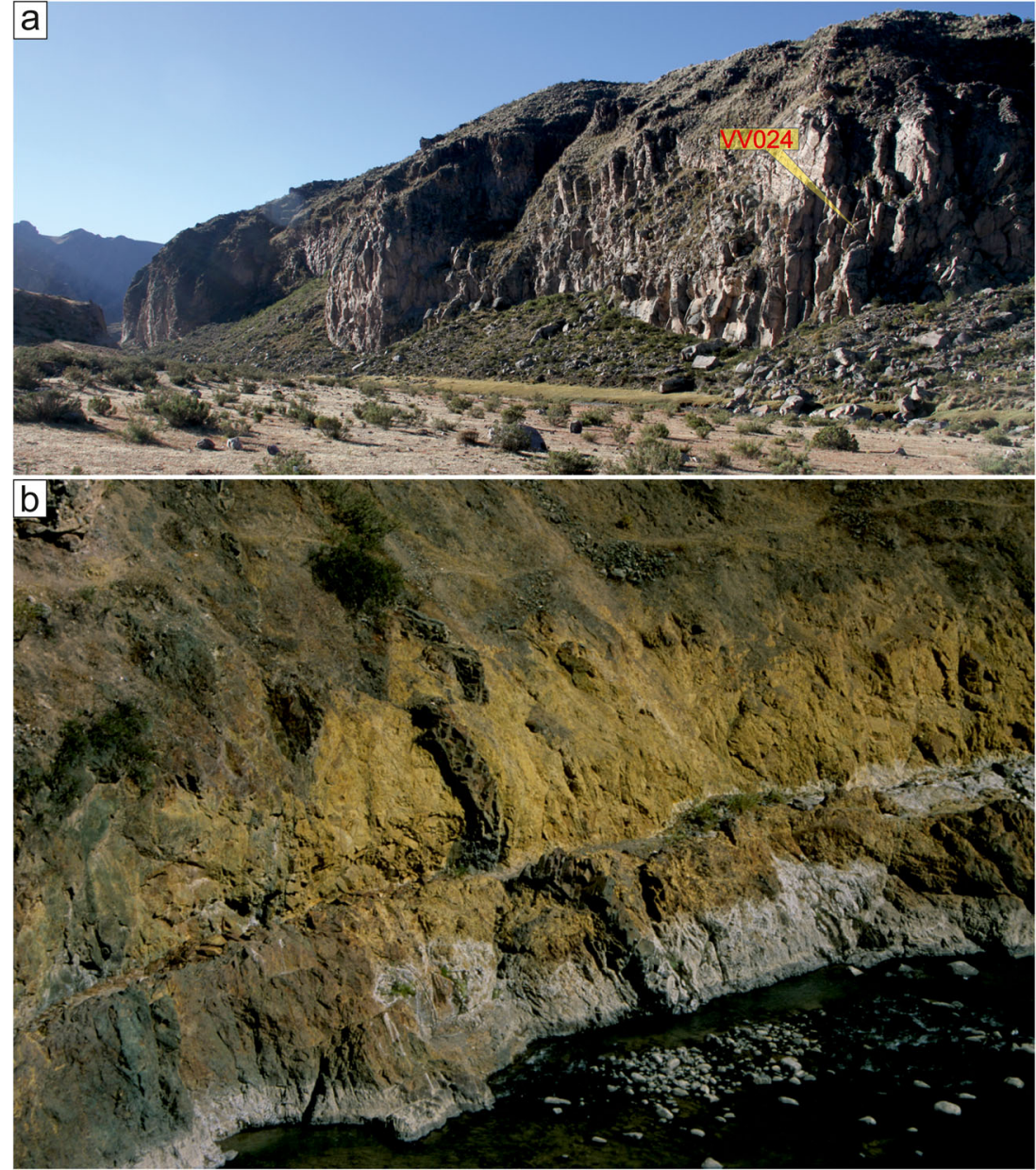

samples from the Puca Mauras volcanic complex, the largest volcanic center in this area, were performed using inductivelycoupled-plasma mass-spectrometry in a certified laboratory.

Garnet crystals were initially observed using secondary electron imaging with a FEI Quanta 200 FEG electron probe micro-analyser (EPMA). Subsequently, wavelength dispersive X-ray spectrometry (WDS) was used for quantitative analysis performed using a JXA-8230 electron microprobe. Analytical conditions for the WDS analyses were as follows: $15 \mathrm{kV}$ accelerating voltage, $1-5 \mu \mathrm{m}$ beam size and 5-20 nA beam current depending on the material analyzed. Following $\mathrm{X}$-ray lines, detector types and natural and synthetic calibrant materials were used: $\mathrm{F}-(\mathrm{K} \alpha$, TAP, fluorite $), \mathrm{Na}, \mathrm{Al}, \mathrm{Si}-$ (K $\alpha$, TAP, albite), $\mathrm{Mg}-(\mathrm{K} \alpha$, TAP, diopside $), \mathrm{P}-(\mathrm{K} \alpha$, $\left.\mathrm{PET}, \mathrm{YPO}_{4}\right), \mathrm{S}-(\mathrm{K} \alpha, \mathrm{PET}$, anhydrite $), \mathrm{Cl}-(\mathrm{K} \alpha, \mathrm{PET}$, tugtupite), $\mathrm{K}-(\mathrm{K} \alpha$, PET, sanidine), $\mathrm{Ca}-(\mathrm{K} \alpha$, PET, diopside), Ti - (K $\alpha$, PET, rutile), $\mathrm{V}-(\mathrm{K} \alpha, \mathrm{PET}$, metallic vanadium), $\mathrm{Cr}-\left(\mathrm{K} \alpha, \mathrm{LIF}, \mathrm{Cr}_{2} \mathrm{O}_{3}\right), \mathrm{Mn}-(\mathrm{K} \alpha, \mathrm{LIF}$, rhodonite), $\mathrm{Fe}-$ (K $\alpha$, LIF, fayalite), $\mathrm{Sr}-(\mathrm{L} \alpha, \mathrm{PET}$, celestine), $\mathrm{Ba}-(\mathrm{L} \alpha, \mathrm{PET}$, barite). A ZAF correction routine was applied to the raw data. The same instrument was utilized to produce X-ray elemental maps of the garnet using a $15 \mathrm{kV}$ accelerating voltage and a $100 \mathrm{nA}$ beam current, a dwell time of $100 \mathrm{~ms}$ and a pixel size of $1 \mu \mathrm{m}$. The maps were based on the $\mathrm{K} \alpha$ lines of specific elements ( $\mathrm{Mg}, \mathrm{Si}, \mathrm{S}, \mathrm{Ca}$ and $\mathrm{Fe}$ ).

A Thermo Scientific DXR micro-Raman spectrometer was used to obtain Raman spectra of andradite and individual mineral inclusions. A Nd:YAG laser $(532 \mathrm{~nm})$ was used for excitation with power settings ranging from $5 \mathrm{~mW}$ or $10 \mathrm{~mW}$ depending on the mineral stability. Beam was focused onto the samples using a $25 \mu \mathrm{m}$ slit hole aperture and $100 \times$ air objective. The measurments were performed in ambient conditions. Relative band shift due to instrument drift was checked against the known reference material.

\section{Results}

\section{Petrography and geochemistry of the Puca Mauras garnet-hosting rocks}

The rocks from the Puca Mauras lava field are characterized by textural and compositional variability. The lavas show low to medium vesicular, porphyritic or trachytic textures. In contrast, lavas from the foothill of the Puca Mauras cone (Fig. 1c) are more vesicular (up to 20-30 vol\%), contain more glass 
(30 vol\%) and display only a small proportion of plagioclase phenocrysts $(2-5 \mathrm{vol} \%)$. The amount and size of the plagioclase phenocrysts increase with distance from the cone, reaching $20 \mathrm{vol} \%$ and $4 \mathrm{~mm}$ in diameter. Plagioclase is a dominant phenocryst, but minor amphibole and magnetite are also present. Euhedral crystals of amphibole were identified as oxyhornblende (Gałaś 2014). Most of the amphibole crystals are replaced by secondary opaque phases. Samples P7 and P8 (Fig. 1c) contain magnetite as sub- to euhedral phenocrysts and as microphenocrysts or groundmass crystals.

Light grey, massive, aphanitic lavas (VV024) represent a product of effusion from the Huajana lava dome (Fig. 1c). They are not vesicular, but they do contain small voids and fissures ranging from 0.1 to $1.5 \mathrm{~cm}$ in width/ length. $\mathrm{A} \mathrm{SiO}_{2}$ phase, diopside and andradite occur in such voids and fissures. Phenocrysts $(0.1-0.5 \mathrm{~mm}$ in diameter) are scarce and comprise only plagioclase. The groundmass is felsic, mainly built of plagioclase microphenocrysts and a groundmass of plagioclases, clinopyroxene, amphibole, opaque minerals and glass.

In the rocks of the Puca Mauras lava field, the $\mathrm{SiO}_{2}$ content is $60.5-62.0 \mathrm{wt} \%$ (compared to $52.8-67.8 \mathrm{wt} \%$ for all products of AG volcanism). The rocks in question are classified as trachyandesite (latite) on the border with the trachyte field. Their $\mathrm{K}_{2} \mathrm{O}$ content ranges from 2.9 to $3.2 \mathrm{wt} \%$ and $\mathrm{Na}_{2} \mathrm{O}$ from 4.3 to $4.9 \mathrm{wt} \%$. These are the highest values recorded among the AG rocks. On the Harker diagrams, the Puca Mauras samples follow trends outlined for the $A G$, i.e., all major elements are negatively correlated with $\mathrm{SiO}_{2}$, except $\mathrm{K}_{2} \mathrm{O}$ (positive) and $\mathrm{Na}_{2} \mathrm{O}$ (no correlation) (Gałaś 2014, Table 1). A negative correlation of $\mathrm{Sr}, \mathrm{Sm}$ and $\mathrm{Yb}$ to $\mathrm{SiO}_{2}$ is also observed (Fig. 3a-c). In contrast, a positive correlation of $\mathrm{SiO}_{2}$ is observed with $\mathrm{Rb}, \mathrm{Zr}$ and La (Fig. 3d-f). The Puca Mauras rocks, compared to other rocks in the $\mathrm{AG}$, are highly enriched in $\mathrm{SiO}_{2}$, $\mathrm{Rb}, \mathrm{Yb}, \mathrm{Th}$, and relatively depleted in $\mathrm{CaO}, \mathrm{FeO}, \mathrm{MgO}$, $\mathrm{MnO}, \mathrm{V}$, Sr. Chondrite-normalized rare-earth element patterns (Sun and McDonough 1989) show little variability between the analyses of the AG rocks, despite their large aerial extent. When normalized to primitive mantle, they are enriched in large-ion lithophile elements (LILE, e.g. $\mathrm{Ba}$ ), but $\mathrm{Rb}$ and $\mathrm{K}$ do not show a similar trend (Gałaś 2014). In contrast to the other AG rocks, the Puca Mauras lava field displays clear negative $\mathrm{Nb}$ and $\mathrm{Ti}$ anomalies. It can be assumed that fractionation was not as important for its evolution as, for example, contamination. Lavas from the Puca Muras are more evolved compared to the other rocks of the AG.

\section{Garnet and garnet-hosted inclusions}

The Huajana xenoliths (up to $7 \mathrm{~mm}$ in size) are composed of dozens of small andradite crystals (up to $89.5 \mathrm{~mol} \%$ of this
Table 1 Major and selected trace element contents in samples from the Puca Mauras (Puca M.) complex (Andahua Group)

\begin{tabular}{|c|c|c|c|c|c|c|}
\hline \multirow{2}{*}{$\begin{array}{l}\text { Volcano } \\
\text { Sample }\end{array}$} & \multirow{2}{*}{$\begin{array}{l}\text { Huajana } \\
\text { VV024 }\end{array}$} & \multicolumn{2}{|c|}{ Puca M. } & \multicolumn{2}{|l|}{ V8B } & \multirow{2}{*}{$\begin{array}{l}\text { Chipchane } \\
\mathrm{ARCH} 1 * *\end{array}$} \\
\hline & & PM3 & Pachar2 & P7 & P8 & \\
\hline \multicolumn{7}{|c|}{ Major oxides (wt\%) } \\
\hline $\mathrm{SiO}_{2}$ & 60.61 & 60.59 & 60.88 & 61.61 & 62.04 & 61.76 \\
\hline $\mathrm{TiO}_{2}$ & 0.96 & 1.10 & 0.91 & 0.95 & 0.95 & 1.00 \\
\hline $\mathrm{Al}_{2} \mathrm{O}_{3}$ & 15.76 & 16.79 & 16.33 & 16.21 & 15.92 & 15.90 \\
\hline $\mathrm{Fe}_{2} \mathrm{O}_{3}$ & 5.18 & 6.05 & 5.42 & 5.42 & 5.55 & 5.42 \\
\hline $\mathrm{MnO}$ & 0.07 & 0.10 & 0.10 & 0.10 & 0.07 & 0.08 \\
\hline $\mathrm{MgO}$ & 1.96 & 2.14 & 2.02 & 1.99 & 2.02 & 2.23 \\
\hline $\mathrm{CaO}$ & 4.94 & 4.91 & 4.57 & 4.68 & 4.75 & 4.66 \\
\hline $\mathrm{Na}_{2} \mathrm{O}$ & 4.53 & 4.51 & 4.24 & 4.57 & 4.42 & 4.91 \\
\hline $\mathrm{K}_{2} \mathrm{O}$ & 3.02 & 2.95 & 3.22 & 2.98 & 3.07 & 3.02 \\
\hline $\mathrm{P}_{2} \mathrm{O}_{5}$ & 0.45 & 0.48 & 0.46 & 0.42 & 0.43 & 0.47 \\
\hline LOI* & 1.90 & 0.45 & 1.23 & 0.38 & 1.09 & 0.21 \\
\hline Total & 99.38 & 100.10 & 99.37 & 99.32 & 100.30 & 99.65 \\
\hline \multicolumn{7}{|c|}{ Trace elements (ppm) } \\
\hline $\mathrm{Sr}$ & 1008 & 1019 & 793 & 867 & 887 & 913 \\
\hline $\mathrm{Rb}$ & 83 & 84 & 114 & 82 & 80 & 93 \\
\hline $\mathrm{La}$ & 42.3 & 50.2 & 47.7 & 43.3 & 43.4 & 60.3 \\
\hline $\mathrm{Sm}$ & 6.5 & 7.4 & 7.1 & 7.0 & 6.6 & 6.9 \\
\hline $\mathrm{Yb}$ & 1.7 & 1.6 & 1.7 & 1.7 & 1.7 & 1.1 \\
\hline
\end{tabular}

*LOI Loss on ignition

**- data from Gałaś (2014)

Volcanoes and sampling location see Fig. 1c

end-member). Garnet crystals are dark purple to black. The largest grains do not exceed $0.7 \mathrm{~mm}$ in diameter. The individual crystals are euhedral and optically homogeneous (Fig. 4). Hovewer, they exhibit a complex zoning pattern with mottled cores, oscillatory mantles and unzoned rims. Two types of andradite crystals were recognized, distinguishing a Ti-poor type (up to $0.34 \mathrm{wt} \% \mathrm{TiO}_{2}$, $\mathrm{Ti} 0.02 \mathrm{pfu}$ ) and a Ti-enriched type (up to $3.70 \mathrm{wt} \% \mathrm{TiO}_{2}$ and $0.23 \mathrm{Ti}$ pfu). Both types show oscillatory zoned cores which are characterized by the presence of zones enriched and depleted in $\mathrm{Al}^{3+}$. The content of $\mathrm{Fe}^{3+}$ and $\mathrm{Al}^{3+}$ within andradite cores varies in the range of 2.09-6.16 wt\% $\mathrm{Al}_{2} \mathrm{O}_{3}(0.21-0.60 \mathrm{Al} \mathrm{pfu})$ and 22.89$27.42 \mathrm{wt} \% \mathrm{Fe}_{2} \mathrm{O}_{3}\left(1.42-1.74 \mathrm{Fe}^{3+} \mathrm{pfu}\right)$. In general, rims are most enriched in $\mathrm{Fe}^{3+}$, whose content reaches $27.89 \mathrm{wt} \%$ $\mathrm{Fe}_{2} \mathrm{O}_{3}$ (up to $1.76 \mathrm{Fe}^{3+}$ pfu) in inner parts and $28.94 \mathrm{wt} \%$ $\mathrm{Fe}_{2} \mathrm{O}_{3}$ (up to $1.85 \mathrm{Fe}^{3+}$ pfu) in the outer parts of the rims. The $\mathrm{Ti}$ contents in the rims are generally lower than those in the cores and and reach $0.13 \mathrm{wt} \% \mathrm{TiO}_{2}(0.01 \mathrm{Ti}$ pfu $)$ in the Tipoor andradite and $2.85 \mathrm{wt} \% \mathrm{TiO}_{2}(0.18 \mathrm{Ti}$ pfu $)$ in the Ti-rich variety (Table 2, Fig. 5). The core-mantle regions are enriched in $\mathrm{Ca}$ and $\mathrm{Al}$ with respect to the rims, whereas $\mathrm{Fe}$ follows the opposite trend (Fig. 6). The core-mantle regions host numerous inclusions of anhydrite, halite, S- and Cl-bearing silicate 
Fig. 3 Variation in selected trace elements versus $\mathrm{SiO}_{2}$ content $\mathbf{a}$ - $\mathbf{f}$ in bulk-rock samples of the Andahua Group lavas. Red circles, present study (Table 1); open circles, data of Gałaś (2014)
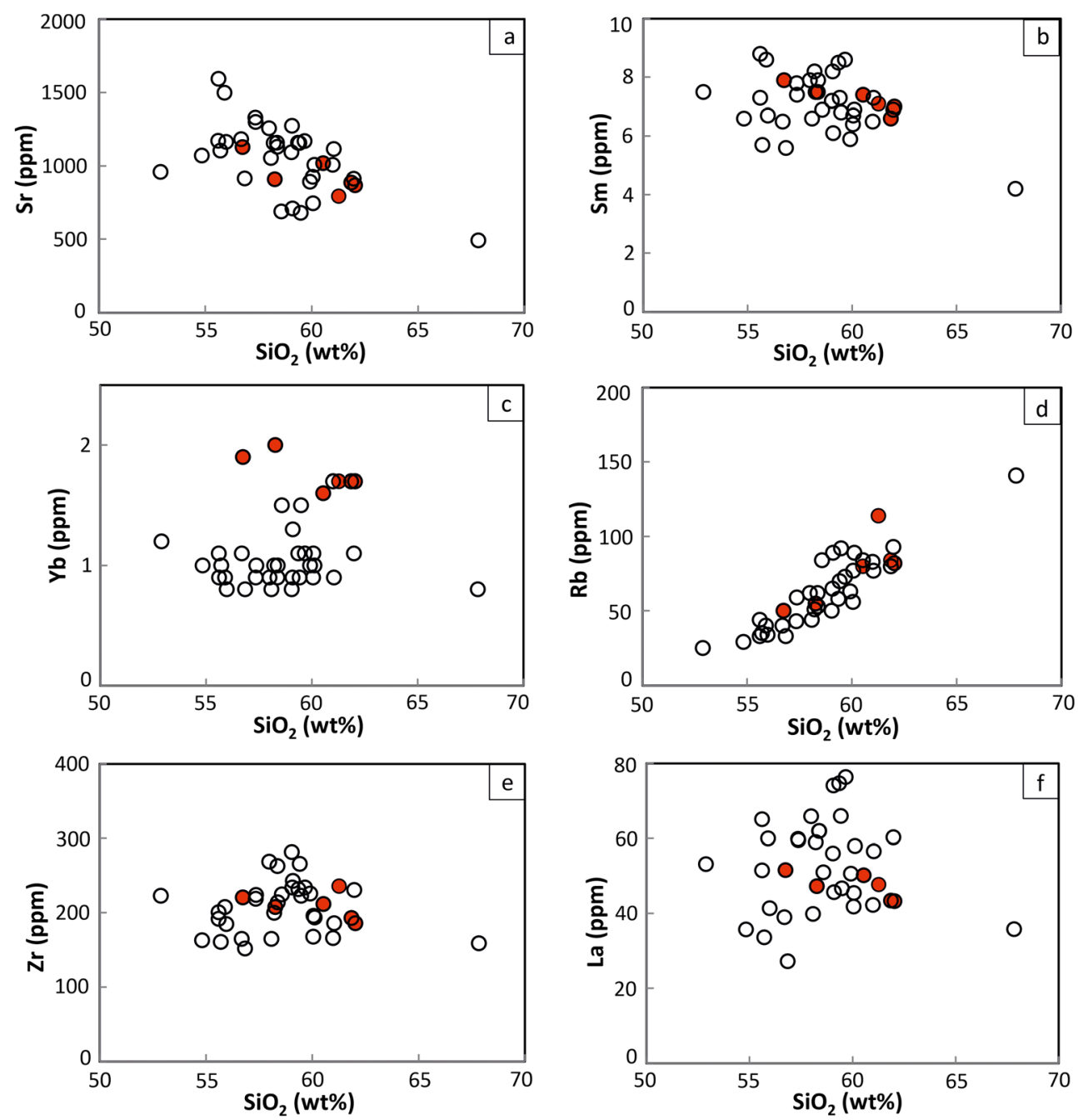

glass (up to $0.1 \mathrm{wt} \% \mathrm{SO}_{3}$ and $1.5 \mathrm{wt} \% \mathrm{Cl}$, respectively), quartz, anorthite $\left(\mathrm{An}_{95}\right)$, wollastonite and magnetite (Table 3; Fig. 7). The rims are essentially devoid of inclusions, but contain scarce diopside-hedenbergite (Table 3).

Raman spectroscopy was used to confirm the assignment of some of the minerals deduced based on EPMA chemical analyses. In the Raman spectrum of andradite (Fig. 8) relatively strong Raman bands occur in three spectral regions: $356-$ $371 \mathrm{~cm}^{-1}, 497-521 \mathrm{~cm}^{-1}$ and $820-879 \mathrm{~cm}^{-1}$, all typical of andradite (Pinet and Smith 1993).

The anhydrite spectrum (Berenblut et al. 1973) is characterized by the strongest band occurring at $1012 \mathrm{~cm}^{-1}$ and slightly weaker bands at $414 \mathrm{~cm}^{-1}, 1109,1127$ and $1158 \mathrm{~cm}^{-1}$ and at 607,625 and $674 \mathrm{~cm}^{-1}$. Weak bands in regions $351-368 \mathrm{~cm}^{-1}, 518 \mathrm{~cm}^{-1}$ and $820-876 \mathrm{~cm}^{-1}$ are related to the Raman spectrum of the surrounding andradite. Raman spectra of the investigated $\mathrm{Fe}^{3+}$-rich member of the diopside-hedenbergite series (Wang et al. 2001) are dominated by several broad bands with maxima located at $325 \mathrm{~cm}^{-1}$, $378 \mathrm{~cm}^{-1}, 528 \mathrm{~cm}^{-1}, 662 \mathrm{~cm}^{-1}, 701 \mathrm{~cm}^{-1}, 763 \mathrm{~cm}^{-1}$ and $1009 \mathrm{~cm}^{-1}$ (Fig. 7). In the Raman spectrum of Fe oxide inclusions, there are three broad bands typical of magnetite spinel (Shebanova and Lazor 2003) at $305 \mathrm{~cm}^{-1}, 542 \mathrm{~cm}^{-1}$ and $669 \mathrm{~cm}^{-1}$ (Fig. 8).

\section{Discussion and conclusions}

Garnet phenocrysts have been previously documented in multiple natural examples of intermediate volcanic rocks (Green and Ringwood 1968; Dingwell and Brearley 1985; Barnes and Allen 2006). The stability of garnet during fractionation of such magmas increases with increasing dissolved $\mathrm{H}_{2} \mathrm{O}$ and probably affects the trace element composition of $\mathrm{H}_{2} \mathrm{O}$-rich volcanic rocks (e.g., Alonso-Perez et al. 2009). On the other hand, garnet in intermediate and felsic volcanic rocks may be of xenocrystic origin (Nitoi et al. 2002; Kawabata and Takafuji 2005). A careful examination of the chemistry and internal zoning of the garnet and its inclusions is required to determine their origin.

The studied andradite crystals were recognized to be of two types: Ti-poor and Ti-enriched. The inclusions found in the 
Table 2 Representative chemical compositions, calculated mineral formulae and calculated endmember fractions for andradite from the Andahua Group lava

\begin{tabular}{|c|c|c|c|c|c|c|c|}
\hline & \multicolumn{3}{|c|}{ Ti-rich andradite } & \multicolumn{4}{|c|}{ Ti-poor andradite } \\
\hline & \multicolumn{2}{|l|}{ Core } & \multirow[t]{2}{*}{ Rim } & \multicolumn{2}{|l|}{ Core } & \multicolumn{2}{|l|}{ Rim } \\
\hline & $\begin{array}{l}\mathrm{Al}- \\
\text { rich }\end{array}$ & $\begin{array}{l}\text { Al- } \\
\text { poor }\end{array}$ & & $\begin{array}{l}\mathrm{Al}- \\
\text { rich }\end{array}$ & $\begin{array}{l}\text { Al- } \\
\text { poor }\end{array}$ & $\begin{array}{l}\mathrm{Al}- \\
\text { rich }\end{array}$ & $\begin{array}{l}\text { Al- } \\
\text { poor }\end{array}$ \\
\hline \multicolumn{8}{|c|}{ Major oxides (wt\%) } \\
\hline $\mathrm{P}_{2} \mathrm{O}_{5}$ & bdl & 0.05 & bdl & bdl & bdl & 0.05 & bdl \\
\hline $\mathrm{TiO}_{2}$ & 0.59 & 3.19 & 2.85 & 0.23 & 0.34 & 0.13 & 0.07 \\
\hline $\mathrm{SiO}_{2}$ & 35.03 & 33.67 & 34.02 & 36.12 & 36.19 & 35.35 & 35.73 \\
\hline $\mathrm{Al}_{2} \mathrm{O}_{3}$ & 4.15 & 2.09 & 1.97 & 6.16 & 2.92 & 1.11 & 3.30 \\
\hline $\mathrm{V}_{2} \mathrm{O}_{3}$ & 0.28 & 0.45 & 0.51 & 0.10 & 0.15 & 0.09 & 0.10 \\
\hline $\mathrm{Fe}_{2} \mathrm{O}_{3} *$ & 25.55 & 27.42 & 27.89 & 22.89 & 26.24 & 28.94 & 26.50 \\
\hline $\mathrm{FeO} *$ & bdl & 0.71 & 1.15 & 0.25 & 1.24 & 1.54 & 1.47 \\
\hline $\mathrm{MnO}$ & 0.11 & 0.25 & 0.28 & 0.19 & 0.24 & 0.40 & 0.51 \\
\hline $\mathrm{CaO}$ & 33.25 & 32.06 & 31.77 & 33.27 & 32.51 & 31.54 & 31.68 \\
\hline $\mathrm{MgO}$ & 0.31 & 0.29 & 0.21 & 0.12 & 0.12 & 0.07 & 0.12 \\
\hline Total & 99.25 & 100.18 & 100.66 & 99.32 & 99.94 & 99.22 & 99.47 \\
\hline \multicolumn{8}{|c|}{ Calculated mineral formulae (apfu)** } \\
\hline $\mathrm{P}^{5+}$ & 0.000 & 0.003 & 0.000 & 0.000 & 0.000 & 0.004 & 0.000 \\
\hline $\mathrm{Si}^{4+}$ & 2.930 & 2.830 & 2.852 & 2.978 & 3.016 & 3.004 & 2.995 \\
\hline $\mathrm{Ti}^{4+}$ & 0.037 & 0.167 & 0.148 & 0.014 & 0.000 & 0.000 & 0.004 \\
\hline $\mathrm{Z}$ & 2.967 & 3.000 & 3.000 & 2.992 & 3.016 & 3.008 & 3.000 \\
\hline $\mathrm{Ti}^{4+}$ & 0.000 & 0.035 & 0.032 & 0.000 & 0.021 & 0.008 & 0.000 \\
\hline $\mathrm{Al}^{3+}$ & 0.409 & 0.207 & 0.194 & 0.599 & 0.286 & 0.111 & 0.326 \\
\hline $\mathrm{V}^{3+}$ & 0.009 & 0.015 & 0.017 & 0.003 & 0.005 & 0.003 & 0.003 \\
\hline $\mathrm{Fe}^{3+}$ & 1.608 & 1.735 & 1.759 & 1.420 & 1.645 & 1.851 & 1.672 \\
\hline $\mathrm{Fe}^{2+}$ & 0.000 & 0.008 & 0.000 & 0.000 & 0.042 & 0.027 & 0.000 \\
\hline $\mathrm{Y}$ & 2.027 & 2.000 & 2.002 & 2.022 & 2.000 & 2.000 & 2.001 \\
\hline $\mathrm{Fe}^{2+}$ & 0.000 & 0.042 & 0.081 & 0.017 & 0.045 & 0.083 & 0.103 \\
\hline $\mathrm{Mn}$ & 0.008 & 0.018 & 0.020 & 0.013 & 0.017 & 0.029 & 0.036 \\
\hline $\mathrm{Ca}$ & 2.980 & 2.888 & 2.853 & 2.939 & 2.903 & 2.872 & 2.846 \\
\hline $\mathrm{Mg}$ & 0.038 & 0.037 & 0.026 & 0.014 & 0.015 & 0.009 & 0.015 \\
\hline$X$ & 3.026 & 2.985 & 2.981 & 2.983 & 2.979 & 2.992 & 3.000 \\
\hline$X+Y+Z$ & 8.020 & 7.985 & 7.983 & 7.997 & 7.995 & 8.000 & 8.000 \\
\hline \multicolumn{8}{|c|}{ Calculated end-member fractions ( $\mathrm{mol} \%)$} \\
\hline$X_{A l m}$ & 0.0 & 1.7 & 2.7 & 0.6 & 2.9 & 3.6 & 3.4 \\
\hline$X_{S p s}$ & 0.3 & 0.6 & 0.7 & 0.4 & 0.6 & 0.9 & 1.2 \\
\hline$X_{P r p}$ & 1.3 & 1.2 & 0.9 & 0.5 & 0.5 & 0.3 & 0.5 \\
\hline$X_{G r s}$ & 19.6 & 9.3 & 8.7 & 29.0 & 14.1 & 5.4 & 15.4 \\
\hline$X_{\text {And }}$ & 77.1 & 78.1 & 78.9 & 68.8 & 81.0 & 89.3 & 79.2 \\
\hline$X_{C a-T i}$ & 1.8 & 9.1 & 8.1 & 0.7 & 1.0 & 0.4 & 0.2 \\
\hline
\end{tabular}

"bdl" means below detection limit

* FeO and $\mathrm{Fe}_{2} \mathrm{O}_{3}$ contents were calculated from charge balance

**Calculated based on 12 oxygen atoms per formula unit cores and rims of the garnet point to their different origins. Anhydrite, halite and S-Cl-bearing glass inclusions in the cores clearly suggest a sulfate-, halide- and Ca-rich source. Although anhydrite can be found as a primary igneous phase in volcanic rocks (e.g., Luhr 2008), its occurrence within xenoliths entrained in volcanic rocks is more likely (e.g., at the classical locality on Santorini; Lacroix 1893). The observed mottled zoning in the cores and oscillatory zoning in the 
Table 3 Chemical composition, calculated mineral formulae and calculated end-member fractions for mineral and glass inclusions in andradite from the Andahua Group lava

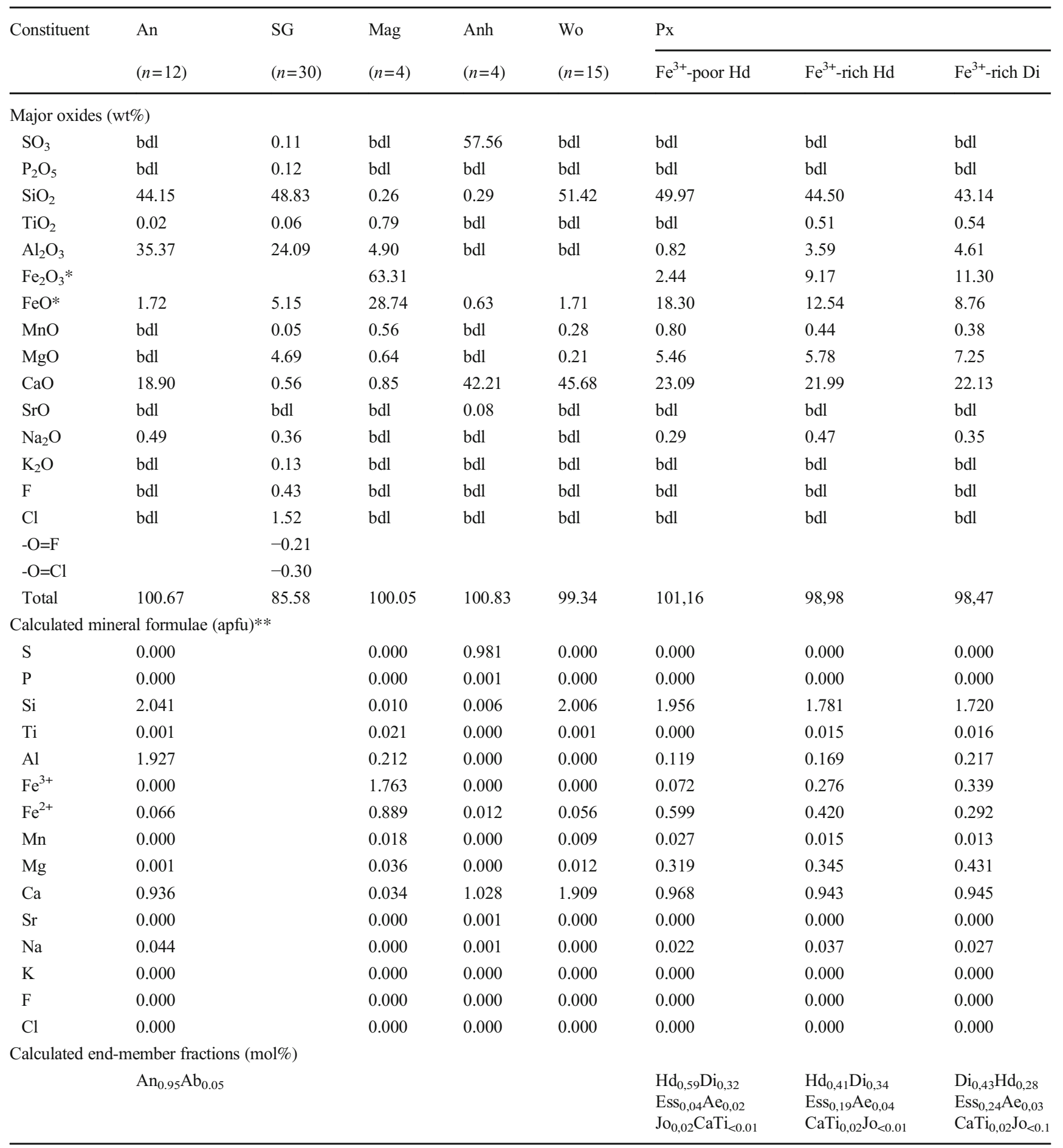

"bdl" - below detection limit; abbreviations: Ab - albite; An - anorthite. Anh - anhydrite, Mag - magnetite, SG - silicate glass, Px - pyroxene (Ae aegirine, $\mathrm{Ca}-\mathrm{Ti}$ - Ca-Ti-pyroxene, $\mathrm{Di}$ - diopside, Ess - esseneite, $\mathrm{Hd}$ - hedenbergite, Jo - johannsenite, Wo - wollastonite). $* \mathrm{FeO}^{2}$ and $\mathrm{Fe} \mathrm{O}_{2} \mathrm{O}_{3}$ were calculated on the basis of the charge balance in pyroxene and magnetite; ${ }^{*}$ Chemical formulae were calculated at the basis of $4 \mathrm{O}^{2-}$ for magnetite and anhydrite, $6 \mathrm{O}^{2-}$ for wollastonite and pyroxene and $8 \mathrm{O}^{2-}$ for anorthite

mantles of garnet crystal could have formed as a result of fluid-assisted precipitation (Harlov and Austrheim 2012) in a xenolith that was subjected to an abrupt change in temperature. Subsequent devolatilization of sulfates and halides (and perhaps carbonates) must have caused abrupt changes in the local chemical environment that is expressed 
Fig. 4 Garnet aggregate in sample VV024 (secondary electron image)

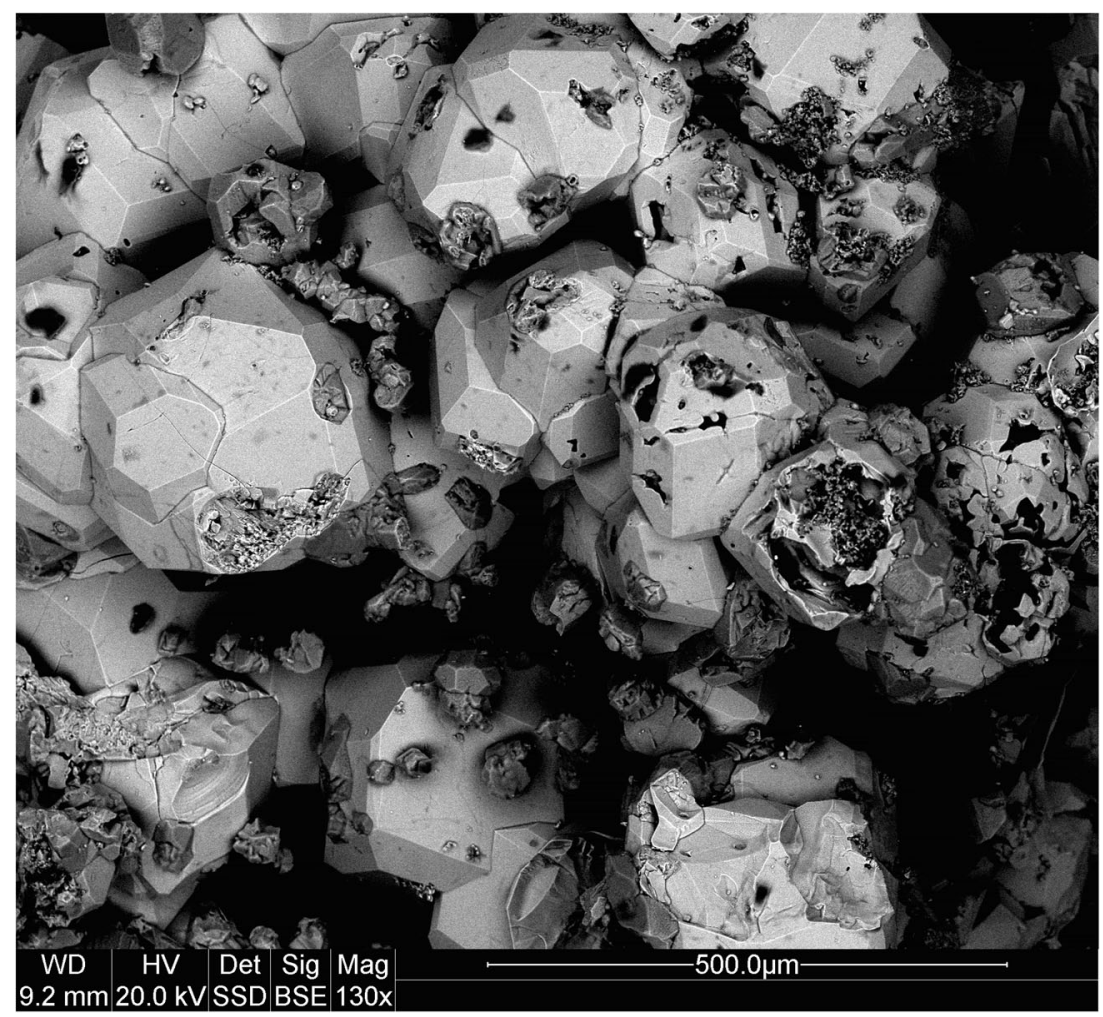

in the peculiar zoning pattern of the garnet. This process could have been associated with contact metamorphism along magma conduits, although it could have also ocurred in an evaporite xenolith already captured by the trachyandesitic magma. However, even after the bulk of the xenolith was devolatilized, the garnet kept growing producing well-
Fig. 5 Compositional variation (a - d) of andradite crystals from Andahua Group lavas
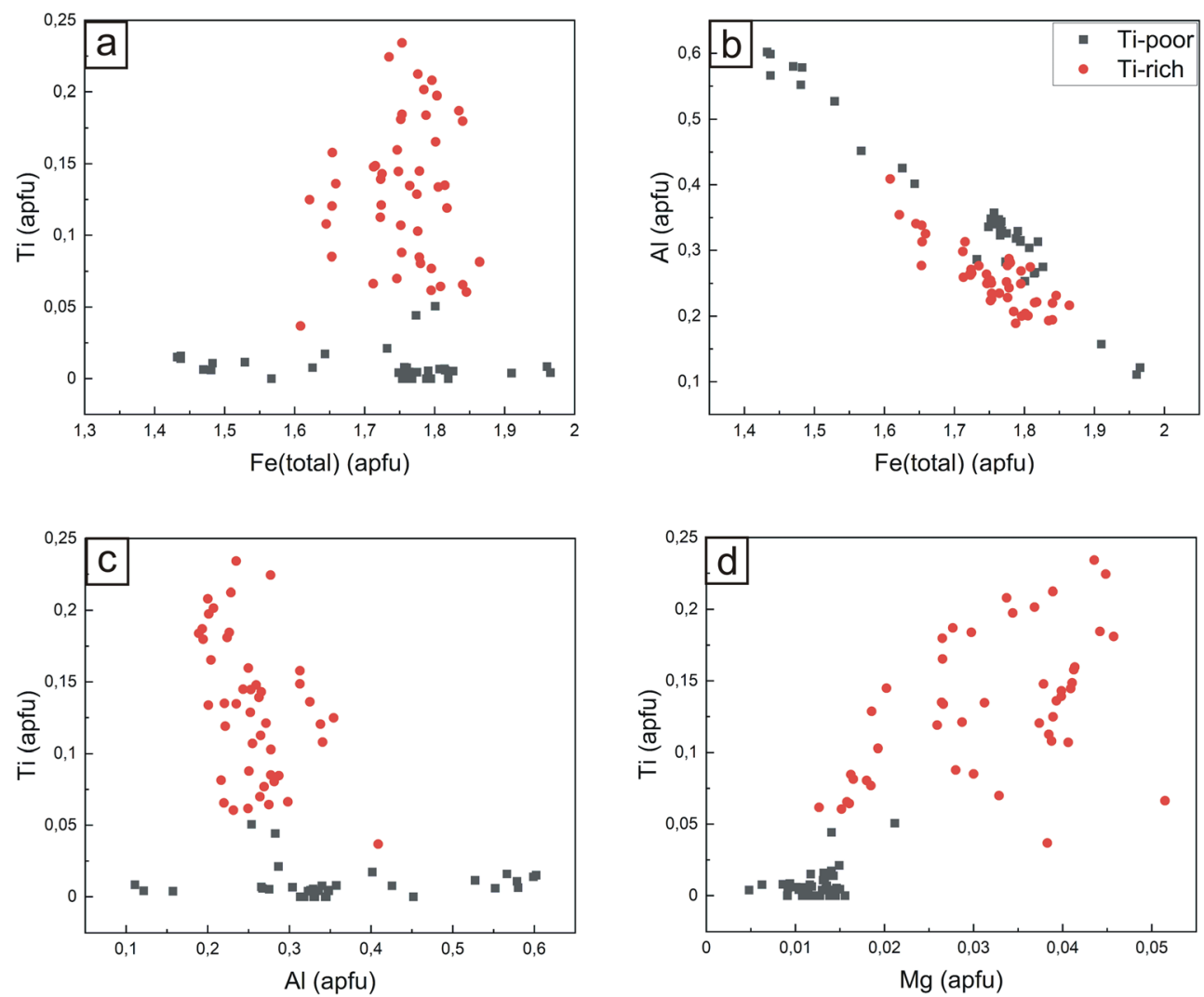

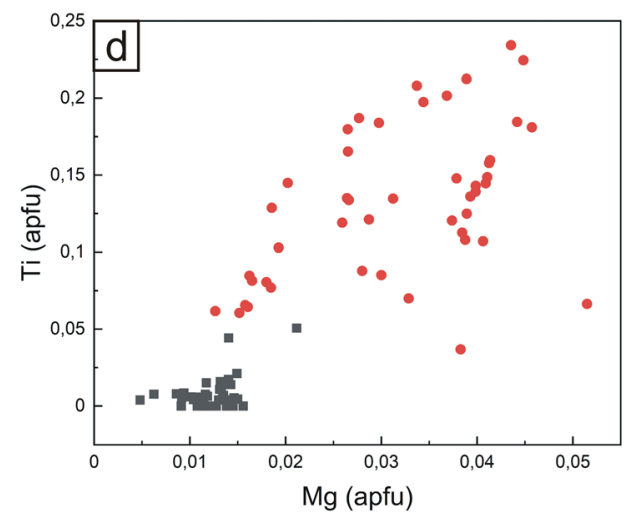


Fig. 6 Complex major element zoning of the studied andradite (a) and (b). Warmer colours denote higher concentrations; the red rectangle indicates the area shown in Fig. 6b; Abbreviations: An anorthite; Anh - anhydrite; Mag magnetite; SG - silicate glass; Wo - wollastonite

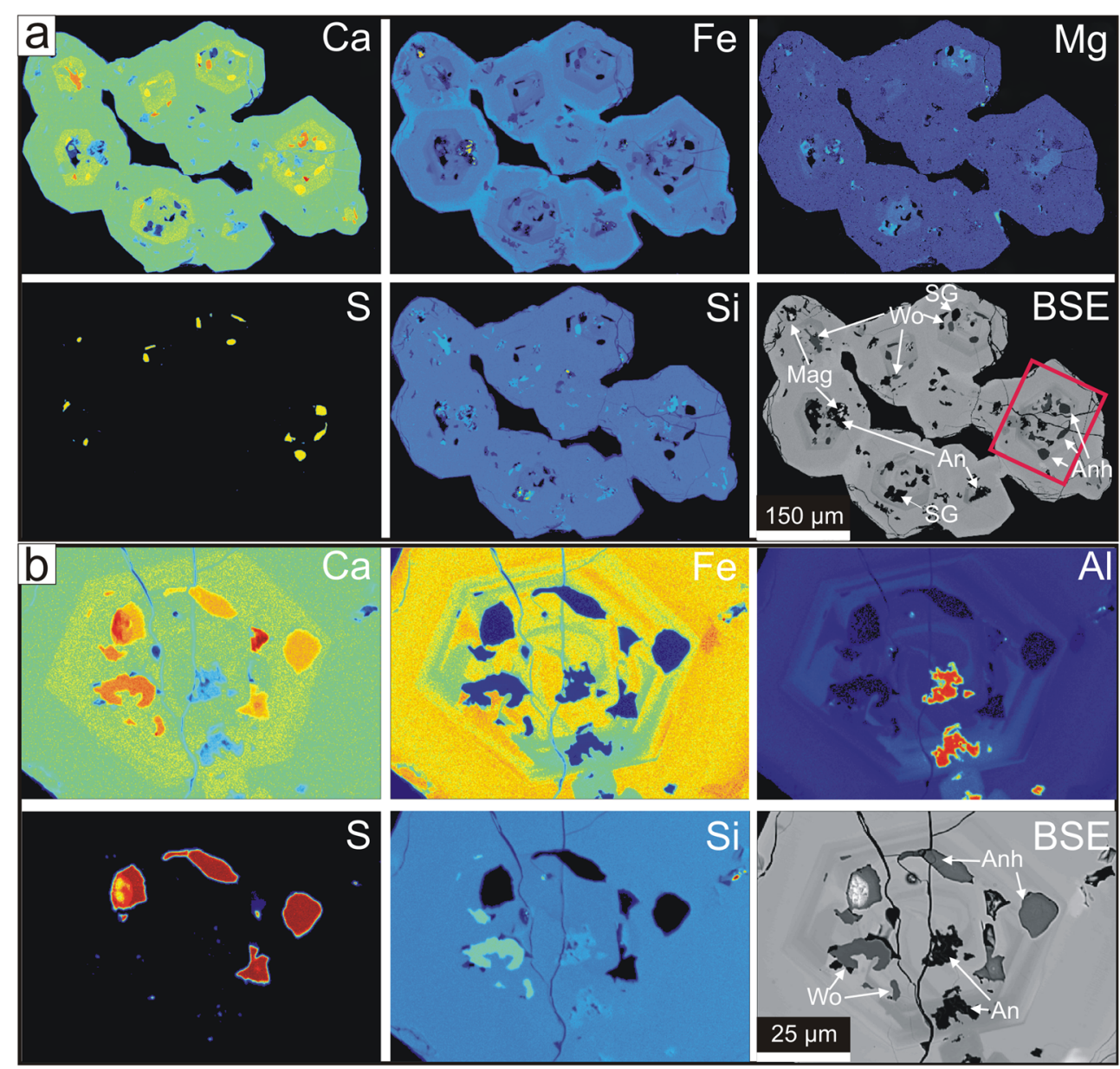

developed unzoned rims. The Fe-rich rims were probably equilibrated with the host magma. The occurrence of hedenbergite inclusions in this outermost zone supports this interpretation, since clinopyroxene of such composition is commonly found in trachytes (e.g., Macdonald et al. 2011). Interestingly, some of the clinopyroxenes enclosed in the studied garnet inclusion are enriched in the esseneite component (up to $29 \mathrm{~mol} \%$ ). This is indicative of extreme, even pyrometamorphic conditions (e.g., Grapes 2006). Thermal regime of this process could be deduced from the presence of halite, which melts at $\sim 800-820^{\circ} \mathrm{C}$ at $P<1 \mathrm{kbar}$ (Akella et al. 1969), and the absence of silvialite (Goldsmith 1976). Hence, we suggest that the outermost zones of the garnet formed in the boundary zone between a devolatilized xenolith and
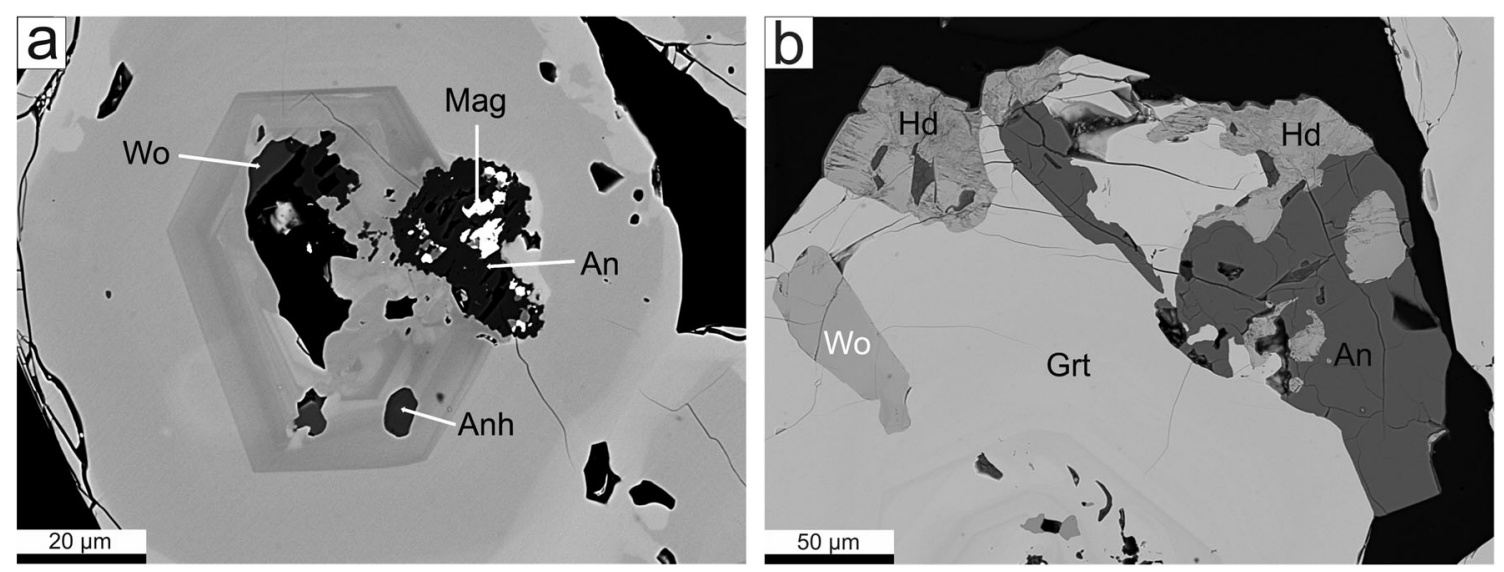

Fig. 7 Backscattered electron images of the inclusions from the garnet core (a) and the garnet rim (b). Abbreviations: An - anorthite; Anh - anhydrite; Grt - garnet; Hd - hedenbergite; Mag - magnetite; Wo - wollastonite 
Fig. 8 Representative Raman spectra of andradite and inclusions in it from the Andahua Group lava

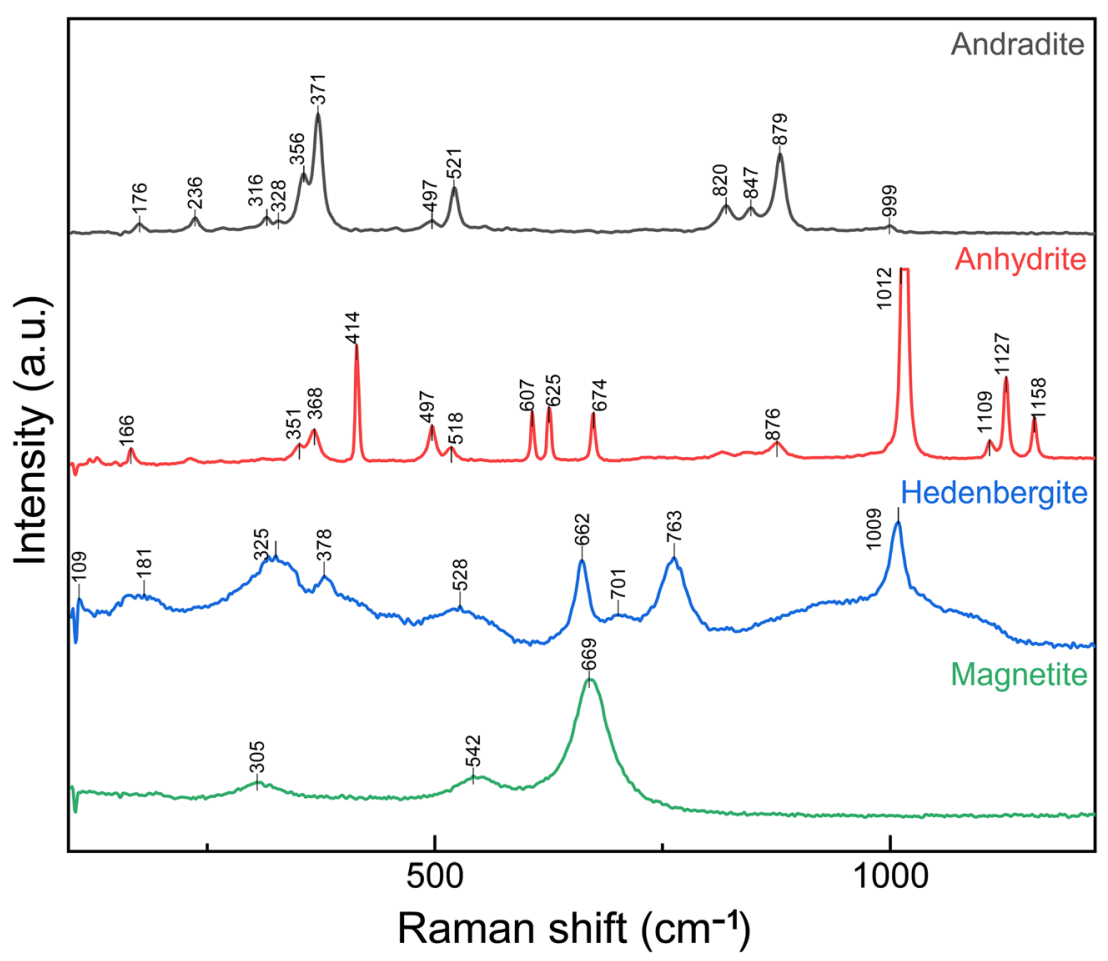

magma under high-T conditions. These observations suggest a mixed metamorphic-magmatic origin of the rims of the Huajana andradite.

Taking into account the above evidence, we postulate that the AG trachyandesite entrained xenoliths of an evaporitebearing wall rock. Such evaporite-bearing sedimentary sequences crop out in the study region and are well-exposed in the hanging walls of the graben which is downfaulted $\sim 2 \mathrm{~km}$ and hosts the AG volcanic centers (Gałaś 2011, Fig. 1c). Thus, the assimilation of xenoliths probably happened at depths of $2-4 \mathrm{~km}$. The ascending magma is interpreted to have caused contact metamorphism of the wall rock, whereas the growth of garnet rims and aggregation of crystals occurred contemporaneously with the entraiment of the xenoliths.

It is not known if the AG trachyandesitic magma was stored in a complex system of magma chambers and pockets rooted in the evaporites. Thus, the real magnitude of contact metamorphism in the studied region is impossible to assess based on the data presented here. However, the fact of interaction between the trachyandesitic magma and evaporites seems unequivocal, as evidenced by the presence of garnet aggregates that represent remnants of evaporite-bearing xenoliths. Such interaction must have resulted in contact metamorphic changes on a much larger scale in the wall rock than within the magma. Assuming a buildup of magma pockets, and the formation of intrusions like dikes or sills (the former commonly observed in the region, Fig. 2b), the degree of contact metamorphism associated with the AG trachyandesites could have been significant. This, in turn, may have resulted in occasional but voluminous emissions of gases liberated through devolatilization of evaporitic minerals, especially sulfates.

In a broader sense, the evolutionary model for monogenetic volcanoes proposed for the Northern Andean segment by Murcia et al. (2019), considering the possible role of various crustal wall rocks that contaminated the ascending magmas, could be plausibly applied to the AG, as well. This model assumes the existence of multiple smaller reservoirs, in which the magma was potentially heterogenous. In the case of the AG, it is obvious that the location of the volcanic activity with respect to different bedrock lithologies plays an absolutely crucial role and influences the character of the ascending magma. Hence, based on this study, it is proposed that the AG volcanic rocks can have a more complicated evolution than hitherto recognized, and they may have been affected by substantial crustal contamination. This interpretation calls for thorough reconsideration of the existing, rather simplistic models that have thus far been proposed for the study area. More universally, the AG may serve as a unique research site for testing the interaction of variously sourced sulfur with magma. The presented results also suggest that the AG volcanoes may have produced significant $\mathrm{SO}_{\mathrm{x}}$ emissions. Reactivation of these volcanoes can potentially represent a great threat to both local population and tourists visiting the Geopark Colca and Volcanoes of Andagua.

Acknowledgements The authors thank reviewer Károly Németh, an anonymous reviewer and journal editor Anton Chakhmouradian for 
their constructive comments that improved this manuscript. Bulk rock chemical analyses were performed at ACTLABS Ltd. (Canada) on a commercial basis. This research was supported by AGH University of Science and Technology, Krakow, Poland grant 16.16.140.315.

Open Access This article is licensed under a Creative Commons Attribution 4.0 International License, which permits use, sharing, adaptation, distribution and reproduction in any medium or format, as long as you give appropriate credit to the original author(s) and the source, provide a link to the Creative Commons licence, and indicate if changes were made. The images or other third party material in this article are included in the article's Creative Commons licence, unless indicated otherwise in a credit line to the material. If material is not included in the article's Creative Commons licence and your intended use is not permitted by statutory regulation or exceeds the permitted use, you will need to obtain permission directly from the copyright holder. To view a copy of this licence, visit http://creativecommons.org/licenses/by/4.0/.

\section{References}

Akella J, Vaidya SN, Kennedy GC (1969) Melting of sodium chloride at pressures to 65 kbar. Phys Rev 185:1135-1140

Alonso-Perez R, Müntener O, Ulmer P (2009) Igneous garnet and amphibole fractionation in the roots of island arcs: experimental constraints on andesitic liquids. Contrib Mineral Petrol 157:541-558

Barnes CG, Allen CM (2006) Depth of origin of late Middle Jurassic garnet andesite, southern Klamath Mountains, California. In: Geological Studies in the Klamath Mountains Province, California and Oregon (eds Snoke AW, Barnes CG). Geol Soc Am Spec Pap 410:269-286

Baxter EF, Caddick MJ, Ague JJ (2013) Garnet: common mineral, uncommonly useful. Elements 9:415-419

Beck S, Zandt G, Myers SL, Wallace T, Silver P, Drake LP (1996) Crustal thickness variations in the Central Andes. Geology 24: 407-410

Berenblut BJ, Dawson P, Wilkinson GR (1973) A comparison of the Raman spectra of anhydrite $\left(\mathrm{CaSO}_{4}\right)$ and gypsum $\left(\mathrm{CaSO}_{4} \cdot 2 \mathrm{H}_{2} \mathrm{O}\right)$. Spectrochim Acta A 29:29-36

Bromley GRM, Thouret JC, Schimmelpfennig I, Mariño J, Valdivia D, Rademaker K, del Pilar S, Team ASTER, Aumaître G, Bourlès D, Keddadouche K (2019) In situ cosmogenic $3 \mathrm{He}$ and $36 \mathrm{Cl}$ and radiocarbon dating of volcanic deposits refine the Pleistocene and Holocene eruption chronology of SW Peru. Bull Volcanol 81:64

Cabrera M, Thouret JC (2000) Volcanismo monogenético en el sur del Perú. X Congr Peruano de Geol. Sociedad Geológica del Perú, Lima (in Spanish)

Caldas J, La Torre V, Lajo A, Díaz J, Umpire L (2001) Mapa geológico del cudrángulo de Orcopampa (actualizado) 1:100 000 . INGEMMET, Peru (in Spanish)

De Paolo DJ (1981) Trace-element and isotopic effects of combined wallrock assimilation and fractional crystallization. Earth Planet Sci Lett 53:189-202

De Silva SL, Francis PW (1991) Volcanoes of the Central Andes. Springer Verlag, Berlin

De Silva SL, Kay SM (2018) Turning up the heat: high-flux Magmatism in the Central Andes. Elements 14:245-250

Delacour A, Gerbe MC, Thouret JC, Wörner G, Paquereau-Lebti P (2007) Magma evolution of quaternary minor volcanic centres in southern Peru, Central Andes. Bull Volcanol 69:581-608

Dingwell DB, Brearley M (1985) Mineral chemistry of igneous melanite garnets from analcite-bearing volcanic rocks, Alberta. Canada Contrib Mineral Petrol 90(1):29-35
Duffield WA, Bacon CR, Dalrymple G (1980) Late Cenozoic volcanism, geochronology, and structure of the Coso range, Inyo County, California. J Geophys Res 85:2381-2404

Gałaś A (2011) The extent and volcanic structures of the quaternary Andahua group, Andes, southern Peru. Ann Soc Geol Pol 81(1): $1-19$

Gałaś A (2014) Petrology and new data on the geochemistry of the Andahua volcanic group (Central Andes, southern Peru). J S Am Earth Sci 56:301-315

Gałaś A, Paulo A, Gaidzik K, Zavala B, Kalicki T, Churata D, Gałaś S, Mariño J (2018) Geosites and Geotouristic attractions proposed for the project Geopark Colca and volcanoes of Andagua, Peru. Springer, Geoheritage 10:707-729

Goldsmith J (1976) Scapolites, granulites, and volatiles in the lower crust. Geol Soc Am Bull 87:161

Grapes R (2006) Pyrometamorphism. Springer-Verlag, Berlin, Heidelberg

Green TH, Ringwood AE (1968) Origin of garnet phenocysts in calcalkaline rocks. Contrib Mineral Petrol 18:63-17

Harlov D, Austrheim H (2012) Metasomatism and the chemical transformation of rock: the role of fluids in terrestrial and extraterrestrial processes. Springer Verlag, Berlin

Huang F, Sørensen EV, Holm PM, Zhang ZF, Lundstrom CC (2017) Useries disequilibria of trachyandesites from minor volcanic centres in the Central Andes. Geochim Cosmochim Acta 215:92-104

Kaneoka I, Guevara C (1984) K-Ar determinations of late tertiary and quaternary Andean volcanic rocks, southern Peru. Geochem J 18: 233-239

Kawabata H, Takafuji N (2005) Origin of garnet crystals in calc-alkaline volcanic rocks from the Setouchi volcanic belt, Japan. Mineral M 69(6):951-971

Kay SM, Godoy E, Kurtz A (2005) Episodic arc migration, crustal thickening, subduction erosion, and magmatism in the south-Central Andes. Geol Soc Am Bull 117:67-88

Kereszturi G, Németh K (2011) Shallow-seated controls on the evolution of the upper Pliocene Kopasz-hegy nested monogenetic volcanic chain in the Western Pannonian Basin (Hungary). Geol Carpath 62(6):535-546

Klerkx J, Deutsch S, Pichler H, Zeil W (1979) Strontium isotopic and trace element data bearing on the origin of Cenozoic volcanic rocks of the central and southern Andes. J Volcanol Geotherm Res 2:49 71

Lacroix A (1893) Les enclaves des roches volcaniques. Protat, Freres, Macon (in French)

Le Maitre RW, Bateman P, Dudek A, Keller J, Lameyre J, Le Bas M, Sabine PA, Schmid R, Sørensen H, Streckeisen A, Wooley AR, Zanettin B (1989) A classification of igneous rocks and glossary of terms: recommendations of the International Union of Geological Sciences Subcommission on the systematics of igneous rocks. Blackwell Scientific Publications, Oxford

Lewińska P, Gałaś A (2021) Use of structure-from-motion algorithms for geomorphological analyses of simple volcanic structures: a case study of Chilcayoc Chico and four other volcanoes of the Andahua group, Peru. J S Am Earth Sci. https://doi.org/10.1016/j. jsames.2020.103058

Luhr JF (2008) Primary igneous anhydrite: Progress since its recognition in the 1982 El Chichón trachyandesite. J Volcanol Geotherm Res 175(4):394-407

Macdonald R, Bagiński B, Leat PT, White JC, Dzierżanowski P (2011) Mineral stability in peralkaline silicic rocks: information from trachytes of the Menengai volcano. Lithos 125:553-568

Mamani M, Wörner G, Sempere T (2010) Geochemical variations in igneous rocks of the central Andean orocline $\left(13^{\circ} \mathrm{S}\right.$ to $\left.18^{\circ} \mathrm{S}\right)$ : tracing crustal thickening and magma generation through time and space. Geol Soc Am Bull 22(1/2):162-182 
Mariño J, Zavala B (2016) Proyecto: Geoparque Valle de los Volcanes, Unidades Geológicas. INGEMMET, Perú (in Spanish)

Mégard F (1987) Cordilleran Andes and marginal Andes: a review of Andean geology north of the Arica Elbow $\left(18^{\circ} \mathrm{S}\right)$. In: Monger, JWH, Fracheteau J (eds.) Circum-Pacyfic orogenic belts and evolution of the Pacific Ocean Basin. American Geophysical Union, Geodynamic Series Washington 18

Murcia H, Borrero C, Németh K (2019) Overview and plumbing system implications of monogenetic volcanism in the northernmost Andes' volcanic province. J Volcanol Geotherm Res 383:77-87

Nitoi E, Munteanu M, Marincea S, Paraschivoiu V (2002) Magmaenclave interactions in the East Carpathian Subvolcanic Zone, Romania: petrogenetic implications. J Volcanol Geotherm Res 118(1-2):229-259

Noble D, Navarro P, Quispesivana L, Peters L, McKee E, (2003) Ash flow sheets of Early Miocene and early Pliocene age are present in the Castillo de Callali, Arequipa department, southern Peru. Boletino Sociedad Geológica del Perú, 95 7:33-38

Paulo A (2008) Geology of the Western Cordyliera in southern Peru - an outline. In: Paulo a, and Gałaś a, (red.) - Polskie badania w Kanionie Colca i Dolinie Wulkanów. Kwartalnik AGH, Geologia 34(2/1):3553 (in Polish with English abstract)

Pinet M, Smith DC (1993) La microspectrométrie Raman des grenats $\mathrm{X}_{3} \mathrm{Y}_{2} \mathrm{Z}_{3} \mathrm{O}_{12}$ : I. La série calcique naturelle ouvarovite-grossulaireandradite. Schweiz Mineral Petrogr Mitt 73:21-40

Reyes-Guzmán N, Siebe C, Oryaëlle Chevrel M, Guilbaud MN, Salinas S, Layer P (2018) Geology and radiometric dating of Quaternary monogenetic volcanism in the western Zacapu lacustrine basin (Michoacán, México): implications for archeology and future hazard evaluations. Bull Volcanol 80:18

Salcedo CJ (2007) Mapa Geologico Departamental de Arequipa 1: 500 000 (digital). INGEMMET, Lima

Samaniego P, Rivera M, Mariño J, Guillou H, Liorzou C, Zerathe S, Delgado R, Valderrama P, Scao V (2016) The eruptive chronology of the Ampato-Sabancaya volcanic complex (southern Peru). J Volcanol Geotherm Res 323:110-128

Sébrier M, Soler P (1991) Tectonics and magmatism in the Peruvian Andes from late Oligocene time to present. Geol Soc Am Spec Pap 265:259-278

Shebanova ON, Lazor P (2003) Raman spectroscopic study of magnetite $\left(\mathrm{FeFe}_{2} \mathrm{O}_{4}\right)$ : a new assignment for the vibrational spectrum. J Solid State Chem 174:424-430
Smith IEM, Németh K (2017) Source to surface model of monogenetic volcanism: a critical review In: Németh $\mathrm{K}$, Carrasco-Nuñez G, Aranda-Gomez JJ, Smith IEM (Editors) Monogenetic Volcanism. Geol Soc Lond Spec Publ The Geological Society Publishing House, Bath UK pp 1-28

Sørensen EV, Holm PM (2008) Petrological inferences on the evolution of magmas erupted in the Andagua Valley, Peru (central volcanic zone). J Volcanol Geotherm Res 177:378-396

Spear FS (1993) Metamorphic phase Equilibria and pressuretemperature-time paths. Monograph, Mineralogical Society of America, Washington DC

Sun SS, McDonough WF (1989) Chemical and isotopic systematics of oceanic basalts: implications for mantle composition and processes. In: Saunders AD, Norry MJ, (red.) Magmatism in the ocean basins. Geol Soc Lond Spec Publ 42:313-345

Swanson E, Noble D, Connors K, Mayta O, Mckee E, Sánchez A, Heizler M (2004) Mapa geológico del cuadrángulo de Orcopampa (Sur del Perú). INGEMMET. Boletín, Serie A 137 (in Spanish)

Thouret JC, Jicha BR, Paquette JL, Cubukcu EH (2016) A 25 myr chronostratigraphy of ignimbrites in South Peru: implications for the volcanic history of the Central Andes. J Geol Soc 173:734-756

Trumbull RB, Wittenbrink R, Hahne K, Emmermann R, Büsch W, Gerstenberger H, Siebel W (1999) Evidence for late Miocene to recent contamination of arc andesites by crustal melts in the Chilean Andes $\left(25^{\circ}-26^{\circ} \mathrm{S}\right)$ and its geodynamic implications. J S Am Earth Sci 12:135-155

Venturelli G, Fragipane M, Weibel M, Antiga D (1978) Trace element distribution in the Cenozoic lavas of Nevado Coropuna and Andagua Valley, Central Andes of southern Peru. Bull Volcanol 41(3):213-228

Wang A, Jolliff BL, Haskin LA, Kuebler KE, Viskupic KM (2001) Characterization and comparison of structural and compositional features of planetary quadrilateral pyroxenes by Raman spectroscopy. Am Mineral 86:790-806

Wörner G, Mamani M, Blum-Oeste M (2018) Magmatism in the Central Andes. Elements 14(4):237-244

Yuan X, Sobolev SV, Kind R (2002) Moho topography in the Central Andes and its geodynamic implication. Earth Planet Sci 199:389-402

Publisher's note Springer Nature remains neutral with regard to jurisdictional claims in published maps and institutional affiliations. 